\title{
A new species of Aurigoniella Takiya, Mejdalani \& Felix (Hemiptera, Cicadellidae, Cicadellini) from southern Brazil ${ }^{1}$
}

\author{
Rodney Ramiro Cavichioli² \& Daniela Maeda Takiya ${ }^{3}$
}

\begin{abstract}
${ }^{1}$ Contribution 1814 of the Departamento de Zoologia, Universidade Federal do Paraná.
${ }^{2}$ Departamento de Zoologia, Universidade Federal do Paraná, Caixa Postal 19020, 81531-980 Curitiba-PR, Brasil. Fellowship CNPq I. cavich@ufpr.br

${ }^{3}$ Laboratório de Entomologia, Departamento de Zoologia, Universidade Federal do Rio de Janeiro, Caixa Postal 68044, 21941-971 Rio de Janeiro-RJ, Brasil. takiya@ufrj.br
\end{abstract}

\begin{abstract}
A new species of Aurigoniella Takiya, Mejdalani \& Felix (Hemiptera, Cicadellidae, Cicadellini) from southern Brazil. Aurigoniella meridionalis, sp. nov. is described and illustrated from Morretes and São José dos Pinhais, Paraná State, southern Brazil. It can be easily distinguished from the Aurigoniella type-species, A. dutrai, by its distinct color pattern, smaller size, shorter crown, hindleg knees attaining lateral lobe of pronotum, aedeagus broadest height around mid-length, and paraphyses ramus biramous.
\end{abstract}

KEYWORDS. Cicadellinae; Neotropical region; new species; sharpshooter; taxonomy.

RESUMO. Uma nova espécie de Aurigoniella Takiya, Mejdalani \& Felix (Hemiptera: Cicadellidae: Cicadellini) do sul do Brasil. Aurigoniella meridionalis, sp. nov. é descrita e ilustrada de Morretes e São José dos Pinhais, Paraná, sul do Brasil. Ela pode ser diferenciada da espécie-tipo de Aurigoniella, A. dutrai, por seu padrão de coloração distinto, menor tamanho, coroa mais curta, joelhos das pernas posteriores atingindo o lobo lateral do pronoto, edeago com altura mais larga na metade da haste e ramos da paráfise birramados.

PALAVRAS-CHAVE. Cicadellinae; cigarrinha; nova espécie; Região Neotropical; taxonomia.

Aurigoniella Takiya, Mejdalani \& Felix, 2001 was described by Takiya et al. (2001) including a single species, A. dutrai Takiya, Mejdalani \& Felix, 2001 from Itamonte, Minas Gerais State, Southeastern Brazil. Aurigoniella can be distinguished from other Neotropical genera of the Cicadellini by the combination of the following features: (1) crown produced anteriorly, its disk sculptured with punctures; (2) forewing without an anteapical plexus of veins; (3) first tarsomere of hind legs with undifferentiated parallel rows of setae; (4) styles very elongate; (5) aedeagus short and broad, without lateral flanges; (6) paraphyses stalked and symmetrical; and (7) female genital chamber with sclerotized internal sternite VIII (Takiya et al. 2001). The study of specimens collected with light and Malaise traps from Morretes and São José dos Pinhais, Paraná State, resulted in the discovery of a new species of Aurigoniella, which represents the first record of the genus from Southern Brazil.

\section{MATERIAL AND METHODS}

The specimens herein studied are deposited in Coleção Entomológica Pe. Jesus Santiago Moure, Departamento de Zoologia, Universidade Federal do Paraná, Curitiba (DZUP), Coleção Entomológica Prof. José Alfredo Pinheiro Dutra, Departamento de Zoologia, Universidade Federal do Rio de Janeiro, Rio de Janeiro (DZRJ), and Museu Nacional, Universidade Federal do Rio de Janeiro, Rio de Janeiro (MNRJ). Morphological terminology follows mainly Young
$(1968,1977)$ and female genitalia (Nielson 1965). Techniques for preparation of genital structures follow those of Oman (1949). The dissected parts are stored in microvials with glycerin. In quotations of label data, a reversed virgule ( () separates lines on a label.

\section{Aurigoniella meridionalis Cavichioli \& Takiya, sp. nov. (Figs. 1-11)}

Description. Length, male 5.9-6.0 mm; female 5.6-6.5 $\mathrm{mm}$.

Head and thorax. Crown (Fig. 1) produced, anterior margin subacute; median length three-fifths interocular width and two-fifths to half transocular width. Antennal ledges with inconspicuous dentiform projection at anterior portion. Forewings (Fig. 1) without additional transverse veins in anteapical cells; in two male paratypes, apex of inner anteapical cell separated by short distance from base of second apical cell ( $\mathrm{m}-\mathrm{cu}_{3}$ connected to $\mathrm{M}$ and not to $\left.\mathrm{M}_{3+4}\right)$. Hindlegs (Fig. 1) with knees attaining pronotum lateral lobes. Other characteristics as in the generic description (Takiya et al. 2001: 176).

Male genitalia. Pygofer (Fig. 2), in lateral view, slightly produced, posterior margin narrowly rounded; macrosetae distributed from basiventral margin to apical margin; without processes. Valve (Fig. 3), in ventral view, large and subtriangular. Subgenital plates (Figs. 2, 3, 5), in ventral view, triangular, apical third narrower; in lateral view, extending posteriorly almost as far as pygofer apex; with uniseriate 

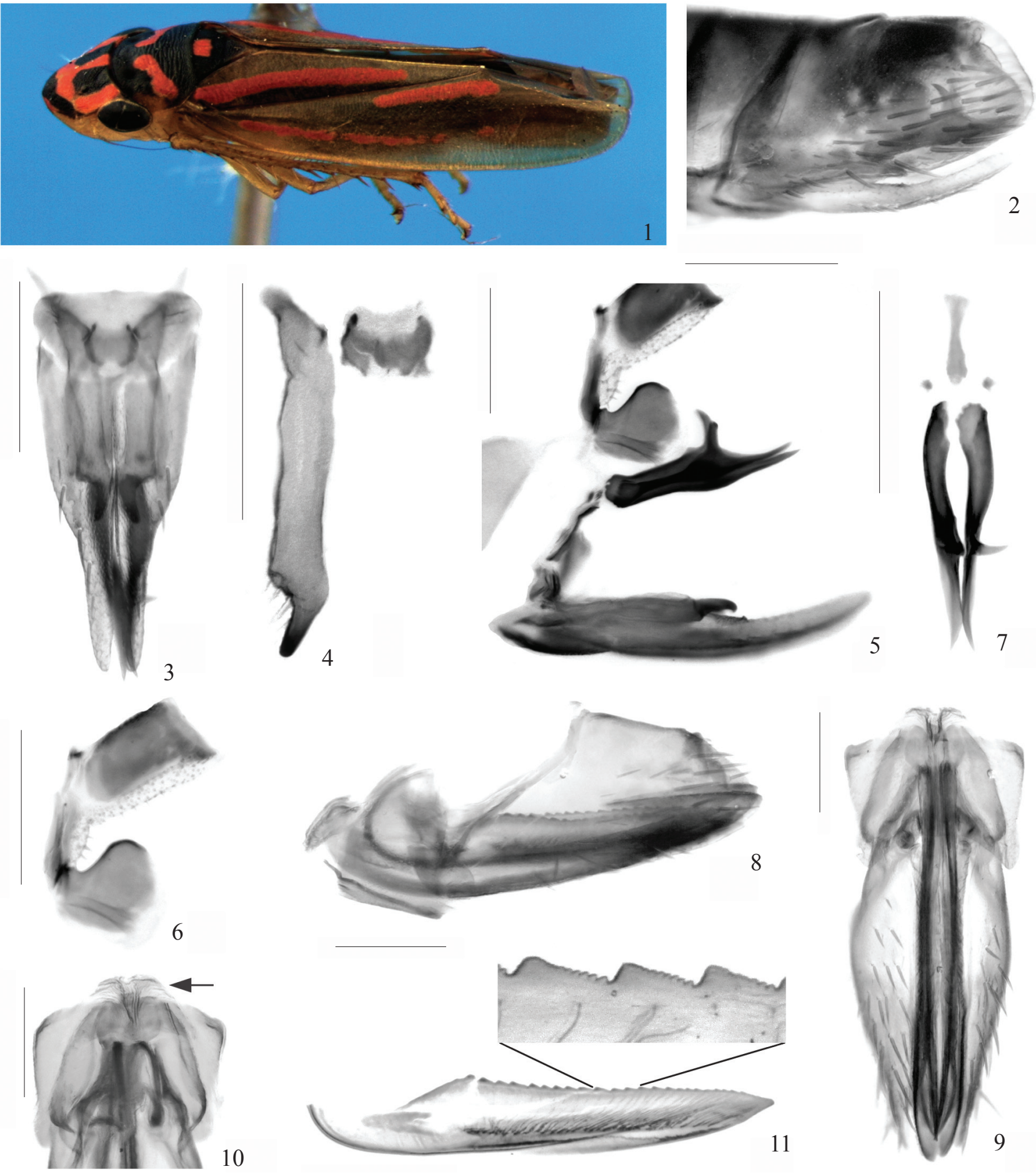

Figs. 1-11. Aurigoniella meridionalis, sp. nov. 1, Female paratype, dorsolateral habitus; 2-7. Male genitalia. 2, Genital capsule, lateral view; 3, Valve and subgenital plates, ventral view; 4, Connective and style, dorsal view (parts are separate); 5, Subgenital plates, connective, styles, paraphyses, aedeagus, and segment $X$ of anal tube, lateral view; 6, Aedeagus and segment X of anal tube, lateral view; 7, Paraphyses, dorsal view; 8-11. Female genitalia. 8, Sternite VII, pygofer, and ovipositor, lateral view; 9, Sternite VII, pygofer, and ovipositor, ventral view; 10, Internal sternite VIII (arrow), dorsal view; 11, Second valvula of the ovipositor with dorsal teeth inset, lateral view. All scale bars $=0.5 \mathrm{~mm}$.

macrosetae on lateral margins; with small dentiform process dorsally on posterior region of median third. Styles (Figs. 4, 5), in dorsal view, very elongate, approximately two-thirds of subgenital plate length; with distinct preapical lobe; apexes divergent and subacute. Connective (Figs. 4, 5), in dorsal view, transversal, very short and wide. Aedeagus (Figs. 5, 6), in lateral view, with shaft short, dorsally expanded, broadest height around mid-length of shaft; apical margin rounded and distinctly membranous; gonopore at ventroapical margin. Paraphyses (Figs. 5, 7), in dorsal view, symmetrical; stem 
short, approximately half ramus length; connection of stem and pair of rami membranous; ramus with elongate projection slightly posterior to mid-length with apex acute and divergent; ramus apex acute and slightly divergent.

Female genitalia. Sternite VII (Figs. 8, 9), in ventral view, short, subquadrate, posterior margin projected into median and two lateral lobes. Internal sternite VIII (Figs. 8, $10)$, in dorsal view, sclerotized into two overlapped plates. Pygofer (Fig. 8), in lateral view, produced; posterior margin slightly angulate; macrosetae distributed from ventral margin to apex. Second valvulae of ovipositor (Fig. 11), in lateral view, broadened beyond basal curvature; dorsal margin almost straight, bearing approximately 23 teeth; each tooth subtriangular with denticles; preapical area with denticles on dorsal and ventral margins; without ventral prominence; apex acute.

Coloration. Crown (Fig. 1) black with large M-shaped orange macula; anterior margin with thin orange transverse stripe between disk and face. Head and thorax ventrally and legs (Fig. 1), yellow. Pronotum black with two oblique orange bands converging anteriorly. Mesonotum black with orange median spot at base. Forewings (Fig. 1) golden-brown with three orange longitudinal stripes: one over most of clavus; one on corium, shorter, parallel to apical portion of claval suture; longer one parallel to costal margin.

Material. Holotype male, "Morretes [approximately 25030'36"S 4848’48”W, 36m asl] - Pr [Paraná] Brasil 16-23/VII/1984\CIIF [Centro de Identificação de Insetos Fitófagos] (Malaise)”, DZUP. Paratypes. 2 males, same data as holotype, DZUP and MNRJ; 1 male and 1 female, same data

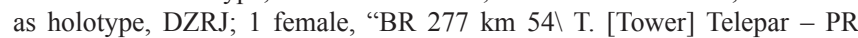
[approximately $25^{\circ} 33^{\prime} 20^{\prime \prime} \mathrm{S} 48^{\circ} 58^{\prime} 21^{\prime \prime} \mathrm{W}, 1,053 \mathrm{~m}$ asl, São José dos Pinhais] 1-VIII-1984\ CIIF (luminosa[light trap])", DZUP.

Taxonomic notes. The two species included in Aurigoniella show very similar morphological characteristics, such as: (1) body somewhat flattened dorsoventrally (Fig. 1); (2) elongate styles (Fig. 4); (3) subgenital plates with dorsal dentiform projection (Fig. 5); (4) short and dorsally expanded aedeagus
(Fig. 6); and (5) little variation in the structures of the female terminalia. However, the new species can be easily distinguished from $A$. dutrai by: (1) distinct color pattern (Fig. 1); (2) smaller body size, A. meridionalis males measuring approximately $6.0 \mathrm{~mm}$ and $A$. dutrai approximately 6.5 mm; (3) crown shorter, approximately six-tenths interocular width, whereas in A. dutrai it is eight-tenths to same as interocular width; (4) hindleg knees attaining lateral lobe of pronotum (Fig. 1); (5) aedeagus broadest height around midlength (Fig. 6), whereas in A. dutrai it is broadest at apex; and (6) paraphyses ramus appearing biramous (Fig. 7), i.e., with elongate process at around mid-length. Additionally, the characteristic short hindfemora of $A$. dutrai, an unusual character for a member of the Cicadellini (Takiya et al. 2001), are not found in $A$. meridionalis.

Biological notes. Although A. dutrai is found in Itamonte region only at altitudes above $1,900 \mathrm{~m}, A$. meridionalis is found at much lower altitudes from $36-1,053 \mathrm{~m}$ asl.

\section{REFERENCES}

Nielson, M. W. 1965. A revision of the genus Cuerna (Homoptera, Cicadellidae). Technical Bulletin of the United States Department of Agriculture 1318: 1-48.

Oman, P. W. 1949. The Nearctic leafhoppers (Homoptera: Cicadellidae). A generic classification and check list. Memoirs of the Entomological Society of Washington 3: 1-253.

Takiya, D. M.; G. Mejdalani \& M. Felix. 2001. A new genus and species of Cicadellini (Hemiptera Cicadellidae Cicadellinae) from Southeastern Brazil. Tropical Zoology 14: 175-183.

Young, D. A. 1968. Taxonomic study of the Cicadellinae (Homoptera: Cicadellidae), Part 1, Proconiini. Bulletin of the United States National Museum 261: 1-287.

Young, D. A. 1977. Taxonomic study of the Cicadellinae (Homoptera: Cicadellidae), Part 2, New World Cicadellini and the genus Cicadella. Technical Bulletin of the North Carolina Agricultural Experiment Station 239: 1-1135. 